\title{
Case Study of Effectiveness Evaluation of Staff Training Courses in Refah Bank
}

\author{
Ebrahim Yousefian \\ Department of Humanities Sciences \\ Faculty of Public Management \\ Khorasgan Branch, Islamic Azad \\ University, Khorasgan, Isfahan, Iran
}

\author{
Ali Chitsaz \\ Department of Management \\ University of Isfahan \\ Isfahan, Iran
}

\author{
Beheshteh Karimpour \\ Department of English Teaching \\ Khorasgan Branch, Islamic Azad \\ University \\ Khorasgan, Isfahan, Iran
}

\begin{abstract}
One of the newest and most well-known train patterns for evaluating the effectiveness of in-service staffs training is Kircpatrick model. In this paper, the effectiveness of staff training courses of Refah-bank is evaluated. A questionnaire consisted of five components which include: reaction, learning, of behavior, the results and the innovation in role of confounding factors is handed out. The survey results show that three factors (reactions, behavior and innovation) have a significant effect on the teachings effectiveness according to Kircpatrick model. And that two factors (learning and results of the courses) have not a significant effect.
\end{abstract}

Keywords-Kircpatrick model; Mebbliav; Training; staff

\section{INTRODUCTION}

The fundamental problem in many training programs is that imparting training to work doesn't move well. The well known Kirkpatrick Model is the worldwide standard for evaluating the effectiveness of training [1]. The variables in this study consist of five cases. Learning model components include response factor (satisfaction and organization of courses and facilities) and learning factors (learner readiness, self-efficacy and performance), behavioral factors (expectations of performance improvement and enhance one's knowledge and changes in behavior and attitudes improvement and enhance one's ability), results elements (results and efficiency training of colleagues, supervisor support, positive individual results, negative individual results, the administrator license, freedom to change and feedback) and innovation factors including (persistent, improvement in work, coordination of training methods and budget with innovation of staff). The main question in this research is that has in-service training courses held synonymous with innovation been effective based on the transition of the model? In this regard, the transition model is one of the newest and the most popular patterns in the evaluating literature of the effectiveness of staff's in-service training that can be used as a convenient and comprehensive tool to assess the effectiveness of in-service staff training. This model with four levels: 1) Reaction 2) Learning 3) behavior 4) Results 5) innovation factors examine the effectiveness of the transition of education. Eventually, the condition of persistence training staffs depends on the level of innovation. If in-service trainings are not properly, results will not be satisfactory. In
[2], authors investigated the relationship between the transmitted training and performance of service organizations in case of Saipa. The results show that all the factors studied on the Halton transition model is desirable. In [3], authors investigated the transition of education in Malaysia's National Automotive Company. Results showed that Halton model in the course of transmission is desirable this has facilitated a positive transition to work and education transfer occurred. In [4], authors evaluated the transition of education in the public administration of Catalonia. Results showed that the motivational elements are the most valuable one followed by work environment factors and transfer of control.

The Refah-kargaran Bank is as an old and reputable bank in Iran that intends to create major developments in staff education and improvement. The aim of the current study is to investigate the effect of in-service training on employee's performance with the interventionist role of innovation based on Kirkpatrick model.

\section{RESEARCH METHODOLOGY}

The study population included all employees of Refah Bank who have completed in-service training (165 people) and 113 are selected. A questionnaire was used as a measuring tool [4]. The first part of the questionnaire included demographic characteristics of respondents such as gender, education, and work experience and organizational position. The second part included 43 knowledge transfer questions. The learning model used includes components such as response factors (satisfaction organizing courses and facilities), learning factors (learner readiness, self-efficacy and performance), behavioral factors (expectations about behavior changes to improve the performance of one's knowledge, improve attitudes promotion and Raising ability), results (results and efficiency training of colleagues, supervisor support, positive individual results, negative Individual results, the administrator license, Freedom to change and feedback) and innovation factors (persistence, work improvement, coordination of training methods and budget) (Table I and Figure 1).

The learning component has earned the most points and this means that in-service training of employees has the greatest impact on learning. Male respondents scored higher than female and they showed more confidence and more belief to 
the effectiveness of in-service training. Younger participants scored higher that the older ones. Interestingly, the innovative component allocated its maximum amount to the much younger group (under 25 years). Graduates also scored higher compared to non-graduates. In fact, bachelor respondents' have shown more confidence and more belief to the effectiveness of in-service training. In terms of innovation, diploma holders scored higher. However, Diploma holders and low literate people scored the lowest in terms of Results for-service training. Experienced respondents (over 21 years of experience) have shown more trust and belief in the effectiveness of in-service training.

TABLE I. CATEGORIES OF INDICATORS ASSOCIATED WITH EACH VARIABLE FOR INVENTORY

\begin{tabular}{|c|c|c|c|}
\hline studied Variables & $\begin{array}{c}\text { Index } \\
\text { number }\end{array}$ & $\begin{array}{c}\text { Cronbach's } \\
\text { alpha }\end{array}$ & questions \\
\hline $\begin{array}{c}\text { Reactive agents } \\
\text { (Satisfaction and organization of } \\
\text { courses and facilities) }\end{array}$ & 9 & 0.74 & $\begin{array}{c}1-2-3-4-5-6- \\
7-14-15\end{array}$ \\
\hline $\begin{array}{l}\text { Learning factors (learner } \\
\text { readiness, self-efficacy and } \\
\text { performance) }\end{array}$ & 8 & 0.55 & $\begin{array}{l}11-12-13- \\
22-23-24- \\
25-26\end{array}$ \\
\hline $\begin{array}{c}\text { Elements behavior } \\
\text { (expectations about behavior } \\
\text { changes to improve performance } \\
\text { and enhance the ability of the } \\
\text { individual) }\end{array}$ & 12 & 0.71 & $\begin{array}{c}8-9-10-30- \\
31-32-33- \\
34-35-36- \\
37-38\end{array}$ \\
\hline $\begin{array}{l}\text { Results (Returns Teaching Fellow, } \\
\text { supervisor support, positive } \\
\text { individual results, negative } \\
\text { personal consequences, } \\
\text { Administrator privileges, freedom } \\
\text { to change and feedback) }\end{array}$ & 9 & 0.78 & $\begin{array}{l}16-17-18- \\
19-20-21- \\
27-28-29\end{array}$ \\
\hline $\begin{array}{l}\text { Innovation Factors (Survival, } \\
\text { improvement in working and } \\
\text { coordinating with innovative } \\
\text { teaching methods and Budget } \\
\text { staff) }\end{array}$ & 5 & 0.69 & $\begin{array}{c}39-40-41- \\
42-43\end{array}$ \\
\hline
\end{tabular}

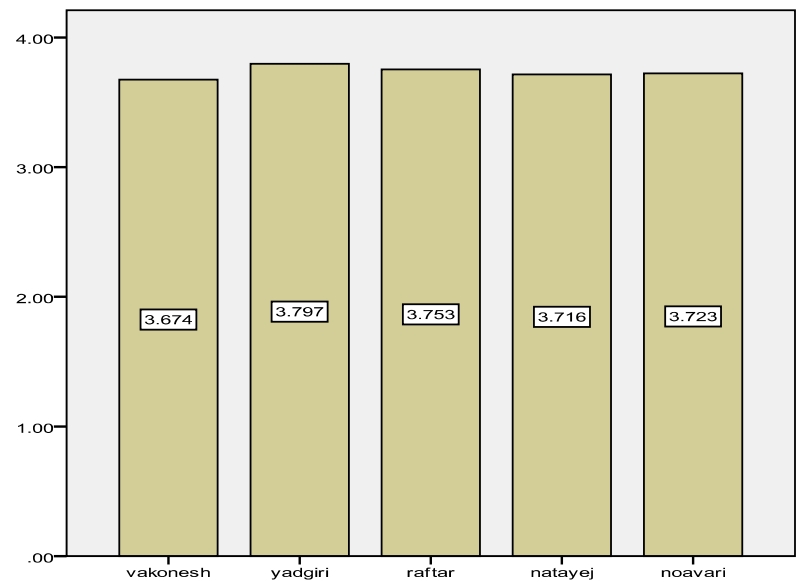

Fig. 1. Results of elements such as innovation agents, learning agents and reactive agents

\section{THE RESULTS OF THE SURVEY}

The results show that there is a significant difference between the mean response element and the effectiveness of the training course. In other words there is a significant relationship between the independent variable (response elements) and the dependent variable (effect of the course). Also, there is a significant relationship between the variables of innovation (as a confounding variable) and the dependent variable (effect of the course). (Significant value $=0.001$ is less than $0.05=\alpha$ ). Auxiliary variables as a moderating variable affect the reactive element to the variable relationship between the variables in the efficacy period (Table II). The results also showed that there is a significant difference between the mean element of learning and the effectiveness of the training course. In other words, there is a significant relationship between the independent variable (the learning element) and the dependent variable (effect of the course). There is a significant relationship between innovation auxiliary variables (as confounding variables) and the dependent variable (the effectiveness of the training course). (Significant value $=0.73$ is greater than $0.05=\alpha$ ). Auxiliary variables as a moderating variable influenced the effectiveness of the course and relationships between learning element to the variable (Table III).

Further, there is a significant difference between the behavior elements and the effectiveness of the training course. In other words there is a significant relationship between the independent variable (behavior elements) and the dependent variable (effect of the course). There is a significant relationship between the Innovation auxiliary variables (as an intervening variable) and the dependent variable (effect of the course). Auxiliary variables as a moderating variable affected the behavior element to the variable relationship (Table IV). There is also a significant difference between the elements of the results and effectiveness of the training course. In other words there is a significant relationship between the independent variable (element results) and the dependent variable (effect of the course). (Significant value $=0.00$ is smaller than the $0.05=\alpha$ ).

There is a significant relationship between innovation auxiliary variables (as confounding variables) and the dependent variable (the effectiveness of training). Auxiliary variables as a moderating variable does not affect result element to effectiveness of variable the efficacy period (Table V). Table VI focuses on the innovation relationship between Refah bank's employees in Isfahan province with the effectiveness of in-service training. The results show that, since the amount is significantly less than 5 percent $\mathrm{HO}$, is rejected and as a result, the correlation between claims (H1) will be accepted. Due to its meaningful value $0.03<0.05$ ) the hypothesis is rejected. This means that there is a significant correlation between effectiveness and innovation. In fact, the innovation doesn't have linear relationship with effectiveness of educational. 
TABLE II. TEST OF EFFECT ON THE EFFECTIVENESS OF THE MEDIATION INNOVATION VARIABLE BY REACTIVE ELEMENT THE DEPENDENT VARIABLE: THE EFFECTIVENESS OF PERIOD

\begin{tabular}{|c|c|c|c|c|c|}
\hline Factors & $\begin{array}{c}\text { Sum of } \\
\text { Squares }\end{array}$ & $\begin{array}{l}\text { Degrees of } \\
\text { freedom }\end{array}$ & \begin{tabular}{|c|} 
Average \\
of squares
\end{tabular} & $\mathrm{F}$ & Meaningful \\
\hline $\begin{array}{l}\text { The corrected } \\
\text { version }\end{array}$ & $4.948^{\mathrm{a}}$ & 14 & 0.353 & 9.418 & 0.000 \\
\hline Intercept & 10.827 & 1 & 10.827 & 288.490 & 0.000 \\
\hline Innovation & 0.498 & 1 & 0.498 & 13.268 & 0.001 \\
\hline Reaction & 4.526 & 13 & 0.348 & 9.277 & 0.000 \\
\hline Error & 2.252 & 60 & 0.038 & & \\
\hline Total & 1053.415 & 75 & & & \\
\hline $\begin{array}{l}\text { The corrected } \\
\text { total }\end{array}$ & 7.200 & 74 & & & \\
\hline
\end{tabular}

TABLE III. TEST THE EFFECT OF LEARNING ON THE EFFECTIVENESS OF THE MEDIATION INNOVATION VARIABLE ELEMENT THE DEPENDENT VARIABLE: THE EFFECTIVENESS OF PERIOD.

\begin{tabular}{|c|c|c|c|c|c|}
\hline Factors & $\begin{array}{l}\text { Sum of } \\
\text { Squares }\end{array}$ & $\begin{array}{l}\text { Degrees of } \\
\text { freedom }\end{array}$ & \begin{tabular}{|c|} 
Average \\
of squares
\end{tabular} & $\mathrm{F}$ & Meaningful \\
\hline $\begin{array}{l}\text { The corrected } \\
\text { version }\end{array}$ & $5.077^{\mathrm{a}}$ & 12 & 0.423 & 12.352 & 0.000 \\
\hline Intercept & 17.024 & 1 & 17.024 & 497.063 & 0.000 \\
\hline Innovation & 0.004 & 1 & 0.004 & 0.115 & 0.736 \\
\hline Reaction & 4.654 & 11 & 0.423 & 12.354 & 0.000 \\
\hline Error & 2.123 & 62 & 0.034 & & \\
\hline Total & 1053.415 & 75 & & & \\
\hline $\begin{array}{l}\text { The corrected } \\
\text { total }\end{array}$ & 7.200 & 74 & & & \\
\hline
\end{tabular}

TABLE IV. THE TEST OF THE BEHAVIORAL IMPACT OF ON THE EFFECTIVENESS OF THE MEDIATION INNOVATION VARIABLE THE DEPENDENT VARIABLE: THE EFFECTIVENESS OF THE PERIOD.

\begin{tabular}{|c|c|c|c|c|c|}
\hline Factors & $\begin{array}{c}\text { Sum of } \\
\text { Squares }\end{array}$ & $\begin{array}{c}\text { Degrees of } \\
\text { freedom }\end{array}$ & $\begin{array}{c}\text { Average of } \\
\text { squares }\end{array}$ & $\mathrm{F}$ & Meaningful \\
\hline $\begin{array}{c}\text { The corrected } \\
\text { version }\end{array}$ & $4.856^{\mathrm{a}}$ & 17 & 0.286 & 6.947 & 0.000 \\
\hline Intercept & 15.562 & 1 & 15.562 & 378.463 & 0.000 \\
\hline Innovation & 0.094 & 1 & 0.094 & 3.291 & 0.014 \\
\hline Reaction & 4.434 & 16 & 0.277 & 6.739 & 0.000 \\
\hline Error & 2.344 & 57 & 0.041 & & \\
\hline Total & 1053.415 & 75 & & & \\
\hline $\begin{array}{c}\text { The corrected } \\
\text { total }\end{array}$ & 7.200 & 74 & & & \\
\hline
\end{tabular}

a. $\mathrm{R} 2=.674$ (justified $\mathrm{R} 2=.577$ )

TABLE V. TEST RESULTS ON THE EFFECTIVENESS OF THE MEDIATION INNOVATION VARIABLE ELEMENT EFFECT THE DEPENDENT VARIABLE: THE EFFECTIVENESS OF THE PERIOD

\begin{tabular}{|c|c|c|c|c|c|}
\hline Factors & $\begin{array}{l}\text { Sum of } \\
\text { Squares }\end{array}$ & $\begin{array}{l}\text { Degrees of } \\
\text { freedom }\end{array}$ & $\begin{array}{c}\text { Average of } \\
\text { squares }\end{array}$ & $\mathrm{F}$ & Meaningful \\
\hline The corrected & $5.991^{\mathrm{a}}$ & 17 & 0.352 & 16.609 & 0.000 \\
\hline version & 13.358 & 1 & 13.358 & 629.583 & 0.000 \\
\hline Intercept & 0.005 & 1 & 0.005 & 0.251 & 0.618 \\
\hline Innovation & 5.568 & 16 & 0.348 & 16.403 & 0.000 \\
\hline Error & 1.209 & 57 & 0.021 & & \\
\hline Total & 1053.415 & 75 & & & \\
\hline $\begin{array}{c}\text { The corrected } \\
\text { total }\end{array}$ & 7.200 & 74 & & & \\
\hline
\end{tabular}

TABLE VI. CORRELATION COEFFICIENT BETWEEN INNOVATION AND EFFECTIVENESS

\begin{tabular}{|c|c|c|}
\hline & Effectiveness & Innovation \\
\hline Pearson Effectiveness & 1 & $0.242^{*}$ \\
\cline { 2 - 3 } $\begin{array}{c}\text { Significantly. (2-sided) } \\
\text { number }\end{array}$ & 75 & 0.036 \\
\cline { 2 - 3 } & $0.242^{*}$ & 75 \\
\hline $\begin{array}{c}\text { Pearson Effectiveness } \\
\text { Significantly .(2-sided) } \\
\text { number }\end{array}$ & 0.036 & 1 \\
\cline { 2 - 3 } & 75 & 75 \\
\cline { 2 - 3 }
\end{tabular}

A. Variable relationship between gender and questionnaire components

Since a significant amount of the element behavior and efficacy is less than 5\% $\mathrm{H} 0$ is rejected. This happens to behavior elements and component of effectiveness of training courses.it means that there is a significant relationship between gender and effectiveness and behavior. However, in reaction, learning, and result elements which are derived from the questionnaires significantly more than $5 \% \mathrm{H} 0$ is not rejected. In fact, these elements don't relate to gender (Table VII).

TABLE VII. CORRELATION COEFFICIENT OF TRANSFER MODELS AND GENDER

\begin{tabular}{|c|c|c|c|c|c|}
\hline & Reaction & Behavioral & Results & Innovation & Effectiveness \\
\hline Pearson gender & -.050 & $-.250^{*}$ & -.223 & -.217 & $-.257^{*}$ \\
\hline $\begin{array}{c}\text { Significantly. } \\
\text { (2-sided) }\end{array}$ & .669 & .030 & .054 & .062 & .026 \\
\hline number & 75 & 75 & 75 & 75 & 75 \\
\hline
\end{tabular}

B. Relationships between age and questionnaire components

Since a significant amount of reactive, results and effectiveness of element is less than $5 \% \mathrm{H} 0$ is rejected. This happens to behavior elements and component of effectiveness of training courses. It means that there is a significant correlation with age between effectiveness and behavior. In fact, these elements have a linear relationship with age. On the other hand in the behavioral elements and innovations which is derived from the questionnaires, there is significantly greater than $5 \% \mathrm{H} 0$ and is not rejected. In fact, these elements are not correlated with age (Table VIII).

TABLE VIII. CORRELATION COEFFICIENT OF TRANSMISSION MODEL AND AGE

\begin{tabular}{|c|c|c|c|c|c|}
\hline & Reaction & Behavioral & Results & Innovation & Effectiveness \\
\hline Pearson age & $0.247^{*}$ & 0.153 & $0.349^{* *}$ & 0.020 & $0.299^{* *}$ \\
\hline $\begin{array}{c}\text { Significantly. } \\
\text { (2-sided) }\end{array}$ & 0.033 & 0.191 & 0.002 & 0.862 & 0.009 \\
\hline number & 75 & 75 & 75 & 75 & 75 \\
\hline
\end{tabular}

C. The relationships between the education and the components of the questionnaire

Since a significant amount of all elements of the questionnaire is more than $5 \% \mathrm{H} 0$ it is not rejected. It happens to the entire questionnaire. This means that there is no significant correlation between the components of the questionnaire and education (Table IX). 
TABLE IX. CORRELATION COEFFICIENT OF TRANSFER MODEL AND EDUCATION

\begin{tabular}{|l|c|c|c|c|c|}
\hline & Reaction & Behavioral & results & Innovation & effectiveness \\
\hline Pearson education & 0.065 & 0.023 & 0.101 & 0.173 & 0.069 \\
\hline $\begin{array}{l}\text { Significantly. } \\
\text { (2-sided) }\end{array}$ & 0.577 & 0.842 & 0.390 & 0.138 & 0.554 \\
\hline number & 75 & 75 & 75 & 75 & 75 \\
\hline
\end{tabular}

D. The relationships between the work experience and the components of the questionnaire

Since a significant amount of elements such reactions, results and effectiveness is less than 5\% $\mathrm{H} 0$ is rejected and As a result, behavioral, result and effectiveness of the training components occurs. There is a relationship between effectiveness and behavior with significant work experience. On the other hand an innovative element derived from the questionnaire responses and significantly higher than the 5 percent $\mathrm{H} 0$ is not rejected. In fact, these elements don't relate to work experience (Table $\mathrm{X}$ ).

TABLE X. CORRELATION COEFFICIENT OF WORK EXPERIENCE AND COMPONENTS OF THE QUESTIONNAIRE

\begin{tabular}{|c|c|c|c|c|c|c|}
\hline \multicolumn{2}{|c|}{} & Reaction & Behavioral & Results & Innovation & Effectiveness \\
\hline \multirow{2}{*}{$\begin{array}{l}\text { Work } \\
\text { exp. }\end{array}$} & $\begin{array}{c}\text { Pearson } \\
\text { Significantly } \\
(2-\text {-sided })\end{array}$ & 0.170 & $0.229^{*}$ & $0.262^{*}$ & 0.067 & $0.299^{* *}$ \\
\cline { 2 - 7 } & number & 75 & 0.048 & 0.023 & 0.569 & 0.009 \\
\hline
\end{tabular}

E. The relationship between inventory positions and the components of the questionnaire

Since a significant amount more than 5\% in all elements of the questionnaire $\mathrm{H} 0$ is not rejected. And there is no significant relationship among the components of the questionnaire and organizational posts (Table XI).
TABLE XI. CORRELATION COEFFICIENT TRANSFER MODEL ELEMENTS AND ORGANIZATIONAL POST

\begin{tabular}{|c|c|c|c|c|c|c|}
\hline \multicolumn{2}{|c|}{} & Reaction & Behavioral & Results & Innovation & Effectiveness \\
\hline \multirow{2}{*}{$\begin{array}{l}\text { Organiz. } \\
\text { position }\end{array}$} & \begin{tabular}{c} 
Pearson \\
\cline { 2 - 7 }
\end{tabular} & 0.125 & 0.096 & 0.166 & 0.024 & 0.140 \\
\cline { 2 - 7 } & numificantly & 0.284 & 0.414 & 0.155 & 0.835 & 0.230 \\
\hline
\end{tabular}

\section{PRACTICAL SUGGESTIONS}

- Training experts can put the metacognitive strategies training program as a part of the Career Points those Employees using them to boost their capabilities in the study.

- Creativity and innovation are the basis of planning educational services So that the understanding of employees and Director goes up in the expertise and competence of education.

\section{REFERENCES}

[1] http://www.kirkpatrickpartners.com/Our-Philosophy/The-KirkpatrickModel

[2] F. Rahimian, C. Moller, "Global ERP Implementations and Harmonization of Practices in Multinational Corporations: A Conceptual Framework", Nineteenth Americas Conference on Information Systems, Chicago, Illinois, August 15-17, 2013.

[3] A. Ahmad, Effectiveness of learning transfer in national dual training system (NDTS), PhD Thesis, Universiti Tun Hussein Onn Malaysia, 2011

[4] C. Quesada-Pallares, "Training transfer evaluation in the Public Administration of Catalonia: the MEVIT factors model", ProcediaSocial and Behavioral Sciences, Vol. 46, No. 1, pp. 1751-1755, 2012

[5] R. R. Kazbour, H. M. McGee, T. Mooney, L. Masica, R. O. Brinkerhoff, "Evaluating the Impact of a Performance-Based Methodology on Transfer of Training", Performance Improvement Quarterly, Vol. 26, No. 1, pp. 5-33, 2013 